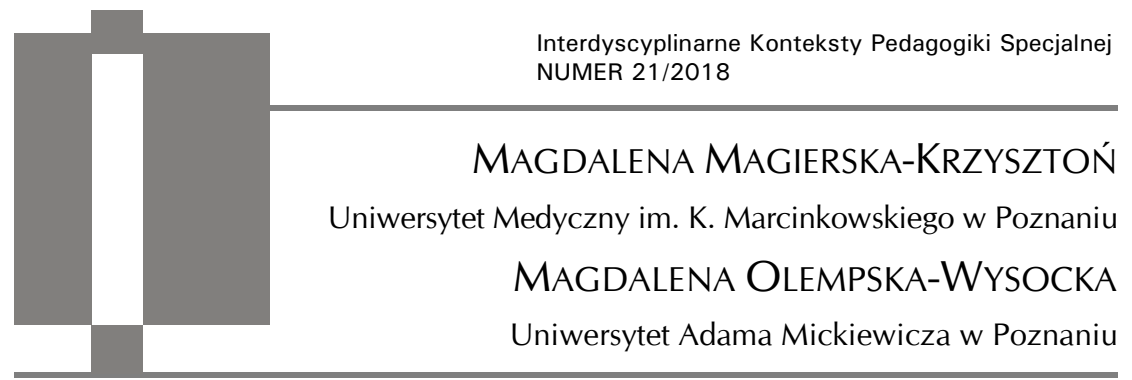

\title{
Kompetencje jezzykowe dzieci z głuchotą prelingwalną zaimplantowanych do drugiego roku życia
}

\begin{abstract}
Magdalena Magierska-Krzyszton, Magdalena Olempska-Wysocka, Kompetencje językowe dzieci z głuchota prelingwalna zaimplantowanych do drugiego roku życia [Language competence of children with prelingual deafness implanted up to the age of two]. Interdyscyplinarne Konteksty Pedagogiki Specjalnej, nr 21, Poznań 2018. Pp. 163-184. Adam Mickiewicz University Press. ISSN 2300-391X. DOI: https:/ / doi.org/ 10.14746/ikps.2018.21.09
\end{abstract}

Early implantation and hearing and speech rehabilitation provide much wider opportunities to develop linguistic and communication skills for children with hearing impairment. The article presents own research, the aim of which was to determine the level of language competence of children with prelingual hearing deafness, which were implanted with a cochlear implant until the second year of life. The study involved a group of 169 children with prelingual hearing deafness. The tests used 6 Ling's sounds, the MAIS scale, the MUSS scale and the TAPS test.

KEY WORDS: cochlear implants, deaf, linguistic and communication skills children's with hearing impairment, prelingual hearing deafness 


\section{Wprowadzenie}

Implanty ślimakowe znacznie zmieniły możliwości rozwoju i kształtowania się kompetencji językowych i komunikacyjnych dzieci z uszkodzonym słuchem. Jak wskazują dane statystyczne, w Zachodniej Europie i Australii ok. 80-90\% dzieci z wrodzoną głuchotą (bez niepełnoprawności sprzężonej) podlega wczesnej implantacji, w USA około $50 \% 1$. W Polsce przez ostanie 25 lat wszczepiono ponad 6000 implantów ${ }^{2}$, a liczba ta z roku na rok powiększa się ${ }^{3}$. Tym samym stwarzane są dzieciom $\mathrm{z}$ niepełnosprawnością słuchową zupełnie nowe możliwości rozwojowe dzięki znacznemu zwiększeniu szans na rozwój tożsamy z rozwojem ich słyszących rówieśników. Nawiązując do teorii krytycznych/wrażliwych etapów w rozwoju mowy dziecka Roberta J. Rubena, należy pamiętać, że istnieją określone ograniczenia czasowe $\mathrm{w}$ nabywaniu umiejętności słuchowych, tworzeniu się połączeń neuronalnych, kształtowaniu się umiejętności rozróżniania fonemów, organizacji dźwięków mowy w większe jednostki, a także nauka języka ojczystego. Jeśli możliwości odbioru wrażeń słuchowych są ograniczone lub niemożliwe, podczas procesu nabywania języka, sieci neuronalne roz-

${ }^{1}$ G. Leigh, J.P. Newall, A.T. Newall, Newborn screening and earlier intervention with deaf children: Issues for developing world, [w:] The Oxford Handbook of deaf studies, language and education, vol. 2, red. M. Marschark, P. Spencer, Oxford University Press, 2010 s. 345-359; S. Broersen, Cochleairr implantaat openet de wereld, "Medisch Contact" 2010, 65, s. 528-531.

2 Liczba ta dotyczy zarówno dzieci, jak i osób dorosłych. Dane statystyczne pozwalają stwierdzić, że od 1992-1998 roku dokonano 130 operacji wszczepienia CI, w tym 55 u dzieci pomiędzy 2,5. a 17. rokiem życia (A. Geremek, H. Skarżyński, Szuchnik J., Program implantów ślimakowych u dzieci - stan obecny, Audiofonologia Tom XIII, Polski Komitet Audifonologii). Do 2008 r. wszczepiono około 2000 CI z czego 63\% stanowiły dzieci (A. Szkiełkowska, H. Skarżyński, A. Piotrowska, A. Lorens, J. Szuchnik, Postępowanie u dzieci ze wszczepami ślimakowymi, „Otorynolaryngologia" 2008, 7(3), s. 121-128).

3 Źródło: https://whc.ifps.org.pl/2018/02/miedzynarodowy-dzien-implantuslimakowego-2/ [dostęp 20.04.2018]. 
winą się bez połączeń słuchowych, które niezbędne są do rozwoju języka werbalnego ${ }^{4}$. Roman Jakobson w opracowanej periodyzacji lingwistycznej podkreśla, że w pierwszym stadium mowy, które stanowi stadium kształtowania się sytemu fonologicznego, chronologia przyswajania dźwięków ma charakter stały, niezależny od kultury i języka, a większość dźwięków przyswajanych jest około drugiego roku życia5. Również Paweł Smoczyński6, sygnalizując swój związek ze strukturalizmem, jednoznacznie i bezpośrednio odwołując się do ustaleń R. Jakobsona, wskazuje, że istotą rozwoju mowy dziecka jest nie tylko opanowywanie przez dziecka fonemu, ale także całego systemu fonologicznego (proces wyrabiania się $\mathrm{u}$ dziecka poczucia struktury fonologicznej słowa). W procesie akwizycji języka dziecko przyswaja elementy systemu z różnych jego poziomów. Każdy z poziomów ma swój własny, wewnętrzny porządek rozwojowy. W teorii tej można zauważyć, że najistotniejsze są dwa pierwsze lata życia dziecka, podczas których dochodzi do: kształtowania się dźwięków mowy, kształtowania sygnalizacyjnej roli krzyku, dochodzi do naśladownictwa i samonaśladownictwa, kształtowania się systemu fonologicznego, znaczenia wyrazów, zmienia się wielkość i struktura słownika, a także dochodzi do kształtowania się składni. Na przełomie drugiego i trzeciego roku życia, a także w drugiej połowie trzeciego roku życia następuje znaczny wzrost słownictwa, rozwój gramatyki, składni, fleksji, semantyki. Istotny jest również fakt, jak wskazuje Robert V. Harrison, że najintensywniejszy rozwój kory słuchowej występuje pomiędzy pierwszym a drugim rokiem życia dziecka?.

4 R.J. Ruben, A Time Frame of Critical/Sensitive Periods of Language Development, “IJO \& HNS" 1999, Vol. 51, No. 3, July-September, s. 85-89.

${ }^{5}$ J. Porayski-Pomsta, O rozwoju mowy dziecka. Dwa studia, Dom Wydawniczy Elipsa, Warszawa, 2015.

${ }^{6}$ P. Smoczyński, Przyswajanie przez dziecko podstaw systemu językowego, Zakład im. Ossolińskich we Wrocławiu, Łódź 1955.

7 R.V. Harrison, Development of the Auditory System. From Periphery to Cortex, [w:] red. Richard C. Seewald, Anne Marie Tharpe, Comprehensive Handbook of Pediatric Audiology, Plural Pub., San Diego 2011. 
Literatura przedmiotu, liczne badania, a także własna praktyka pozwalają zauważyć, że coraz młodsze dzieci są implantowane, przed 12. miesiącem życia, co daje im znacznie szersze możliwości nabywania kompetencji językowej i komunikacyjnej, ale nie oznacza to, jak podkreśla Kazimiera Krakowiak, że sam dostęp do dźwięków mowy wystarczy do pełnej normalizacji rozwoju, a także do pełnej swobody w komunikowaniu się. Istotne jest tutaj wprowadzenie jak najwcześniejszego oraz systematycznego postępowania nie tylko logopedycznego, ale także pedagogicznego i psychologicznego, które będą zmierzały do wyrównania szans, a przede wszystkim do stworzenia każdemu dziecku warunków sprzyjających przyswajaniu języka, rozwoju sprawności komunikowania się w naturalnych warunkach ${ }^{8}$.

\section{Cel badań}

Celem badań było określenie poziomu kompetencji językowych dzieci z głuchotą prelingwalną, które zostały zaimplantowane wszczepem ślimakowym do drugiego roku życia. Autorki poprzez prowadzone badania chcą uzyskać odpowiedzi na następujące pytania badawcze:

1. Czy wczesna implantacja - do drugiego roku życia - umożliwia pełny odbiór dźwięków (w tym dźwięków mowy) na drodze słuchowej?

2. Czy dzieci z głuchotą prelingwalną zaimplantowane wszczepem ślimakowym rozwijają zdolność do różnicowania, rozróżniania, identyfikowania oraz rozumienia dźwięków na drodze słuchowej, co stanowi podstawę do nabywania kompetencji językowych?

3. Czy nabyte i nadal rozwijane kompetencje językowe dzieci zaimplantowanych wszczepem ślimakowym są wystarczające do

${ }^{8}$ K. Krakowiak, Propozycje zmian systemowych w zakresie kształcenia dzieci i mtodzieży ze specjalnymi potrzebami edukacyjnymi spowodowanymi przez uszkodzenia stuchu (niestyszących, stabostyszacych, niedostyszących), "CZŁOWIEK - NIEPEŁNOSPRAWNOŚĆ - SPOŁECZEŃSTWO” 2016, nr 2(32), s. 49-66. 
inicjowania oraz utrzymania kontaktów werbalnych z innymi słyszącymi osobami?

4. Czy język, którym posługują się zaimplantowane dzieci, jest funkcjonalny w aspekcie społeczno-komunikacyjnym?

\section{Materiał, metody}

Badaniami objęto grupę 169 dzieci z głuchotą prelingwalną zaimplantowanych wszczepem ślimakowym. Implantacji dokonano do drugiego roku życia. Operacje przeprowadzono w Klinice Otolaryngologii i Onkologii Laryngologicznej Uniwersytetu Medycznego w Poznaniu. Średni wiek w momencie implantacji dla całej grupy to 15 miesięcy. Wszystkie badane dzieci przed operacją użytkowały przez okres minimum sześć miesięcy aparaty słuchowe. Po operacji 89 dzieci nadal korzystało z aparatów słuchowych, aby optymalnie wzmocnić resztki słuchowe $\mathrm{w}$ uchu niepoddanym implantacji. W badanej grupie było 83 chłopców i 86 dziewczynek. U 20 dzieci specjalistyczne badania potwierdziły genetyczne uwarunkowania głuchoty, pozostała grupa (149 dzieci) prezentowała zróżnicowaną etiologię głuchoty (tabela 1). U 60\% dzieci nie znaleziono żadnej bezpośredniej przyczyny wystąpienia głuchoty, ta grupa wpisuje się jako niesklasyfikowana etiologicznie - przyczyna nieznana. 90\% dzieci $\mathrm{z}$ analizowanej grupy zostało poddanych badaniom przesiewowym słuchu na oddziałach położniczych i neonatologicznych. Głuchota lub głęboki niedosłuch zostały potwierdzone dalszą diagnostyką. 163 małych pacjentów było w normie intelektualnej, a dodatkowe badania i obserwacje nie wykazały współwystępujących dysfunkcji rozwojowych. U sześciu pacjentów z badanej grupy stwierdzono niepełnosprawność intelektualną $\mathrm{w}$ stopniu lekkim i umiarkowanym, a u dwóch dodatkowo współwystępowało niedowidzenie w stopniu znacznym oraz mózgowe porażenie dziecięce, które uniemożliwiło prawidłowy rozwój ruchowy. Sześcioro dzieci urodziło i wychowywało się w rodzinach, gdzie rodzice mieli znaczny niedosłuch i wiodącym językiem w komunikacji rodzinnej był język 
Tabela 1. Etiologia głuchoty: czynniki wrodzone, okołoporodowe, nabyte ( $N=169)$

\begin{tabular}{|l|c|c|}
\hline \multicolumn{1}{|c|}{ Etiologia głuchoty } & $\mathrm{N}$ & $\%$ \\
\hline Czynniki wrodzone & 148 & 87 \\
\hline Czynniki okołoporodowe & 18 & 10 \\
\hline Czynniki nabyte & 3 & 3 \\
\hline
\end{tabular}

Tabela 2. Czas użytkowania wszczepu ślimakowego w badanej grupie $(\mathrm{N}=169)$

\begin{tabular}{|l|c|c|}
\hline $\begin{array}{c}\text { Czas użytkowania wszczepu } \\
\text { ślimakowego }\end{array}$ & $\mathrm{N}$ & $\%$ \\
\hline Od 3 do 6 lat & 66 & 39 \\
\hline Od 6 do 10 lat & 63 & 37 \\
\hline Od 10 do 14 lat & 38 & 22 \\
\hline Powyżej 14 lat & 2 & 2 \\
\hline
\end{tabular}

Tabela 3. Aktualna sytuacja edukacyjna w badanej grupie $(\mathrm{N}=169)$

\begin{tabular}{|l|c|c|c|c|}
\hline $\begin{array}{c}\text { Czas użytkowania } \\
\text { wszczepu }\end{array}$ & Przedszkole & $\begin{array}{c}\text { Szkoła } \\
\text { podstawowa }\end{array}$ & Gimnazjum & $\begin{array}{c}\text { Szkoła } \\
\text { ponadgimnazjalna }\end{array}$ \\
\hline Od 3 do 6 lat & 50 & 16 & 0 & 0 \\
\hline Od 6 do 10 lat & 3 & 60 & 0 & 0 \\
\hline Od 10 d0 14 lat & 0 & 28 & 8 & 2 \\
\hline Powyżej 14 lat & 0 & 0 & 0 & 2 \\
\hline
\end{tabular}

migowy. Ta grupa dzieci od momentu implantacji dodatkowo otoczona była wsparciem ze strony słyszących bliskich (ciocie, wujkowie, babcie i dziadkowie oraz tzw. przyjaciele rodziny), którzy swoją obecnością motywowali i stwarzali sytuacje sprzyjające nabywaniu doświadczeń językowych. Pozostała część badanej grupy (163 dzieci) pochodziła z rodzin, w których wszyscy bliscy posługiwali się mową dźwiękową, a słuch nie odbiegał od normy. Pacjenci od momentu zdiagnozowania głuchoty oraz później po zaimplantowaniu 
objęci byli systematyczną rehabilitacją surdologopedyczną oraz psychologiczną $\mathrm{w}$ placówkach terapeutycznych $\mathrm{w}$ miejscu zamieszkania lub na terenie szkoły lub przedszkola $\mathrm{w}$ przypadku dzieci starszych. Czas użytkowania wszczepu ślimakowego wynosił od minimum trzech lat do 16 (tabela 2). Aktualna sytuacja edukacyjna została przedstawiona $\mathrm{w}$ tabeli 3 .

Poziom rozwoju mowy oralnej i języka przed operacją u ponad 90\% dzieci był szczątkowy, a formy wokalne, którymi się posługiwały, nie mieściły się w systemie językowym. Sposób komunikowania się $\mathrm{z}$ otoczeniem $\mathrm{w}$ tamtym czasie ograniczony był do nieartykułowanych dźwięków oraz gestów i mimiki twarzy, które miały na celu zaspokojenie podstawowych potrzeb dzieci.

W ramach realizacji Poznańskiego Programu Leczenia Głuchoty Metodą Wszczepów Ślimakowych ${ }^{9}$ (Klinika Otolaryngologii i Onkologii Laryngologicznej UM w Poznaniu), specjaliści wypracowali schemat postępowania diagnostyczno-oceniającego, w skład którego wchodzi m.in. wykonywanie $w$ określonych odstępach czasowych badań określoną baterią testów. W badaniach wykonanych na potrzeby tego opracowania posłużono się Testem 6 dźwięków Linga ${ }^{10}$, który dostarczył informacji na temat poziomu percepcji słuchowej $\mathrm{u}$ badanych ${ }^{11}$. Dodatkowo pokazał dynamikę rozwoju umiejętności

${ }^{9}$ W. Szyfter, A. Pruszewicz, Z. Szmeja, E. Szymiec i in., Poznański Program leczenia głuchoty dziecięcej metoda wszczepów ślimakowych, "Otolaryngologia Polska" 1997, Tom L, Suplement 22, s. 174-178.

${ }^{10}$ S. Scollie, D. Glista, J. Tenhaaf, A. Dunn, A. Malandrino, K. Keene, P. Folkeard, Stimuli and normative data for detection of Ling-6 sounds in Hearing Level, "American Journal of Audiology" 2012, Vol. 21, s. 232-241.

${ }^{11}$ Test 6 dźwięków Linga, którego twórcą był Daniel Ling, został opracowany jako szybki i prosty test, którego można użyć, aby sprawdzić dostęp dziecka do minimalnej liczby dźwięków wymaganych do słyszenia, rozumienia i opanowania mowy. Test Linga obejmuje sześć dźwięków mowy: /m/, /u/, /i/, /a/, /sh/ i /s/ (w kolejności od dźwięków niskich do wysokich). Susan Scollie i Danielle Glista z Universtiy of Western Ontario w Kanadzie opracowały w oparciu o podstawowe założenia testu Ling-6 sposób pomiaru stopnia wykrywania dźwięków mowy do użytku w warunkach dostępności i braku dostępności pomocy słuchowych (źródło: 
dyskryminacyjnych oraz identyfikacyjnych $\mathrm{w}$ obrębie prezentowanych fonemów na drodze słuchowej. W Ośrodku Poznańskim Test Linga wykonywany jest do trzech lat od momentu podłączenia procesora mowy lub $\mathrm{w}$ zależności od indywidualnych potrzeb pacjenta.

Do oceny słyszenia i rozumienia dźwięków wykorzystano skalę MAIS (ang. Meaningful Auditory Integration Scale - Skala słyszenia i rozumienia dźwięków), a użycie mowy do podstawowej komunikacji oceniono przy użyciu skali MUSS (ang. Meaningful Use of Speech Scale - Skala użycia mowy do komunikacji). Są to narzędzia, które dostarczają wiedzy dotyczącej funkcjonowania dziecka w wyżej zaznaczonych obszarach, ale wymagają współpracy ze strony rodziców i/lub nauczycieli, gdyż to oni udzielają odpowiedzi na pytania zawarte $\mathrm{w}$ kwestionariuszach. $\mathrm{W}$ przypadku dzieci starszych o wystarczających kompetencjach językowych możliwe jest wypełnianie kwestionariusza przez samych badanych, ale zawsze należy pamiętać, że ocena może być w pewnym stopniu subiektywna. Autorami skali MAIS są: Sheryl Zimmerman-Philips, Mary J. Osberger i Amy M. Robbins ${ }^{12}$. Skalę MUSS opracowało dwóch autorów: Amy M. Robbins oraz Mary J. Osberger ${ }^{13}$. Wykorzystano również test TAPS (ang. Test of Auditory Perception of Speech), który został opracowany na Uniwersytecie w Bazylei na podstawie materiałów rehabilitacyjnych firmy Cochlear AG14. Adaptacji do warunków języka polskiego dokonały Grażyna Demeńko oraz Leon Rychter w ramach Zakładu Fonetyki Akustycznej Instytutu Podstawowych Problemów Technicznych PAN w Poznaniu przy udziale specjalistów zatrudnionych w Katedrze Chorób Ucha, Nosa, Gardła i Krtani

https://www.phonakpro.com/pl/pl/resources/narzedzia-doradcze/dzieci/testmowy/test-mowy-przeglad.html [dostęp: 20.07.2018].

12 A.M. Robbins, Developing meaningful auditory integration in children with cochlear implants „Volta Review” 1990, 92, s. 361-370.

${ }_{13}$ A.M. Robbins, M.J. Osberger, Meaningful Use of Speech Scale, Indiana University School of Medicine, 1991 (źródło: https://digitalcommons.wustl.edu/cgi/view content.cgi?article $=1309 \&$ context=pacs_capstones [dostęp: 20.07.2018].

${ }^{14} \mathrm{~J}$. Reid, B. Bertram, "Tests of Auditory Perception of Speech for Children" by Cochlear AG, Basel, Switzerland, August 1992. 
Uniwersytetu Medycznego w Poznaniu ${ }^{15}$. Test sprawdza umiejętność wykrywania, dyskryminacji, identyfikacji oraz rozpoznawania i rozumienia dźwięków mowy w zestawach zamkniętych i otwartych, na drodze słuchowej. Zaleca się przeprowadzenie testu jeszcze przed operacją, jeśli to możliwe, (w aparatach słuchowych) oraz kolejno po trzech miesiącach, 12 miesiącach i 36 miesiącach użytkowania wszczepu. W badaniach użyto również Arkusz Badań Umiejętności Językowych, którego wyniki pozwoliły na analizę aktualnego funkcjonowania $\mathrm{w}$ zakresie rozumienia, produkcji mowy, zasobu pojęć oraz umiejętności artykulacyjnych dzieci. Dało to możliwość analizy aktualnego poziomu kompetencji językowych zaimplantowanych dzieci. Arkusz Badania Umiejętności Językowych jest narzędziem klinicznym, wewnętrznym - stworzonym na potrzeby realizacji Poznańskiego Programu. Autorkami Arkusza są Magdalena Magierska-Krzysztoń oraz Jolanta Kociemba. Poziom zadań testowych jest zróżnicowany językowo a polecenia i zadania dobierane są w zależności od wieku fizjologicznego oraz słuchowego dziecka liczonego od momentu podłączenia procesora mowy. Wiek fizjologiczny warunkujący określone umiejętności językowe korygowany jest aktualnym wiekiem słuchowym badanego. Badanie wspomnianym narzędziem przeprowadza się po minimum trzech latach użytkowania implantu ślimakowego, biorąc również pod uwagę wcześniej ocenione przedoperacyjne kompetencje językowe badanych dzieci. Arkuszem Badania Umiejętności Językowych przebadano dotychczas 481 pacjentów zaimplantowanych wszczepem ślimakowym w klinice poznańskiej. Autorki nadal prowadzą ciągłe badania i gromadzą informacje w celu oszacowania trafności i przydatności Arkusza Badań Umiejętności Językowych w praktyce klinicznej. Badania testem Linga oraz testem TAPS przeprowadzono trzy miesiące po podłączeniu procesora mowy, a następnie po roku i po trzech latach użytkowania wszczepu ślimakowego. Kategorię IV testu TAPS (rozumienie mowy na drodze słuchowej - zbio-

${ }^{15}$ G. Demeńko, L. Rychter, A. Pruszewicz, Szyfter W., Woźnica B., Testy do badania stuchowej percepcji mowy (TBPSM) dla dzieci z implantami ślimakowymi, "Otolaryngologia Polska" 1996, T. L 50. 
ry zamknięte i otwarte) wykonano również w aktualnym czasie odpowiadającym maksymalnemu indywidualnemu czasowi użytkowania wszczepu.

\section{Wyniki}

Wszystkie badane dzieci - użytkujące wszczep ślimakowy około trzech miesięcy, bezbłędnie wykonały próbę wykrywania fonemów na drodze słuchowej zarówno w teście TAPS jak i Teście 6 dźwięków Linga (tabela 4).

Tabela 4. Wykrywanie fonemów na drodze słuchowej (test TAPS - poziom I, Test 6 dźwięków Linga), N = 169

\begin{tabular}{|c|c|c|}
\hline \multicolumn{3}{|c|}{ Liczba i odsetek dzieci wykonujących poprawnie testy słuchowe } \\
\hline $\begin{array}{c}\text { Wykrywanie fonemów } \\
\text { na drodze słuchowej }\end{array}$ & Test 6 dźwięków Linga & Test TAPS - poziom I \\
\hline $169(100 \%)$ & $169(100 \%)$ & $169(100 \%)$ \\
\hline
\end{tabular}

Tabela 5. Wyniki w Teście TAPS po trzech miesiącach użytkowania wszczepu ślimakowego, poziom II, $\mathrm{N}=169$

\begin{tabular}{|c|c|}
\hline $\begin{array}{c}\text { Percepcja wzorców rytmicznych mowy - poziom } \\
\text { procentowy prawidłowych wykonań }\end{array}$ & Liczba dzieci \\
\hline $70 \%>$ & 155 \\
\hline $50 \%$ & 9 \\
\hline $50 \%<$ & 5 \\
\hline
\end{tabular}

Wyniki uzyskane przez badanych w Teście TAPS oraz w Teście 6 dźwięków Linga w analogicznym interwale czasowym wynoszącym trzy miesiące od podłączenia procesora mowy pokazują, że większość badanych dzieci opanowała umiejętność percepcji wzorców rytmicznych mowy (tabele 5 i 6). Wyżej wspomniana umiejęt- 
ność kształtuje się przeciętnie w okresie do sześciu miesięcy użytkowania wszczepu ślimakowego. Odstępstwo w tym zakresie zauważalne jest w grupie sześciorga dzieci, u których występują współistniejące deficyty rozwojowe $\mathrm{w}$ postaci niepełnosprawności intelektualnej, mózgowego porażenia dziecięcego oraz niedowidzenia. Ta grupa również opanuje wyżej wymienione umiejętności, ale w nieco późniejszym czasie w wyniku zintensyfikowanych oddziaływań stymulacyjno-terapeutycznych.

Tabela 6. Wyniki w Teście 6 dźwięków Linga- dyskryminacja pojedynczych fonemów, po trzech miesiącach użytkowania wszczepu ślimakowego $(\mathrm{N}=169)$

\begin{tabular}{|c|c|}
\hline $\begin{array}{c}\text { Dyskryminacja fonemów na drodze słuchowej - } \\
\text { poziom procentowy prawidłowych wykonań }\end{array}$ & Liczba dzieci \\
\hline $70 \%>$ & 156 \\
\hline $50 \%$ & 9 \\
\hline $50 \%<$ & 4 \\
\hline
\end{tabular}

Wyniki uzyskane w teście TAPS, poziom III, pokazują, że większość dzieci (ponad 60\%) po roku użytkowania wszczepu dobrze sobie radziła z zadaniami wymagającymi umiejętności percepcji cech mowy (w zakresie percepcji elementów suprasegmentalnych i segmentalnych mowy) oraz identyfikacji mowy. Prowadzenie rehabilitacji ukierunkowanej na percepcję dźwięków mowy również umożliwiło osiągnięcie tak dobrych wyników w tak krótkim czasie. Różna liczba sylab w słowach testowych stanowiła wskazówkę umożliwiającą różnicowanie tych dźwięków mowy, których znaczenia dzieci jeszcze nie posiadały. Identyfikacja słów o tej samej liczbie sylab na drodze słuchowej sprawiała badanym dzieciom najwięcej trudności. Związane to było z jeszcze dość niskim poziomem funkcjonowania językowego, manifestującym się niewielkim zasobem słownictwa biernego i czynnego (tabela 7). Identyfikacja pojedynczych fonemów w Teście Linga po roku użytkowania implantu u większości badanych nie stanowiła problemu. Dźwięki 
były prezentowane w postaci wyrażeń dźwiękonaśladowczych, które są nabywane w pierwszej kolejności doświadczania językowego i dlatego dzieci tak dobrze sobie poradziły z tym zadaniem (tabela 8).

Tabela 7. Wyniki w Teście TAPS po roku użytkowania wszczepu ślimakowego, poziom III $(\mathrm{N}=169)$

\begin{tabular}{|c|c|}
\hline $\begin{array}{c}\text { Percepcja cech mowy, identyfikacja mo- } \\
\text { wy - poziom prawidłowych wykonań }\end{array}$ & Liczba dzieci \\
\hline $70 \%>$ & 104 \\
\hline $50 \%$ & 45 \\
\hline $50 \%<$ & 20 \\
\hline
\end{tabular}

Tabela 8. Wyniki w Teście 6 dźwięków Linga - identyfikacja fonemów po roku użytkowania wszczepu ślimakowego $(\mathrm{N}=169)$

\begin{tabular}{|c|c|}
\hline $\begin{array}{c}\text { Identyfikacja fonemów - poziom prawi- } \\
\text { dłowych wykonań }\end{array}$ & Liczba dzieci \\
\hline $70 \%>$ & 145 \\
\hline $50 \%$ & 20 \\
\hline $50 \%<$ & 4 \\
\hline
\end{tabular}

Realizacja zadań testowych na poziomie IV w teście TAPS wymaga znajomości języka na poziomie funkcjonalnym. Zbiory zamknięte zawierają zdania składające się z podmiotu, orzeczenia oraz dopełnienia. Dla prawidłowego wykonania zadań konieczna jest właściwa interpretacja końcówek fleksyjnych, nadających znaczenie poszczególnym wyrazom. Wyniki (tabela 9) pokazują, że 48 dzieci po roku posługiwania się wszczepem- nie osiągnęło wyniku, który stanowiłby 50\% prawidłowych odpowiedzi w obszarze zbiorów językowych zamkniętych. Zadania językowe ze zbioru otwartego nie posiadają w materiale testowym - odpowiednika - to znaczy desygnatu obrazkowego. Odbiór oraz prawidłowa interpre- 
tacja komunikatów językowych na tym poziomie testowym wymaga sprawnego posługiwania się językiem w różnych sytuacjach społecznych. Znajomość języka w aspekcie semantycznym, syntaktycznym oraz morfologicznym jest niezbędna w tym zakresie zadań i gwarantuje sukces komunikacyjny oraz satysfakcję w kontaktach werbalnych z innymi ludźmi. Osiągnięcie wystarczającego poziomu rozumienia mowy na drodze słuchowej w obrębie zadań testowych nawet po trzech latach użytkowania wszczepu okazało się zadaniem niełatwym dla badanej grupy (tabela 9). Krąg tematyczny do

Tabela 9. Wyniki w Teście TAPS w zależności od czasu użytkowania wszczepu, poziom IV $(\mathrm{N}=169)$

\begin{tabular}{|l|c|c|c|c|c|c|}
\hline \multirow{2}{*}{$\begin{array}{c}\text { Czas użytkowania } \\
\text { wszczepu }\end{array}$} & \multicolumn{5}{|c|}{$\begin{array}{c}\text { Liczba dzieci z poszczególnymi poziomami wykonania testu: } \\
\text { rozpoznawanie, rozumienie mowy }\end{array}$} \\
\cline { 2 - 7 } & \multicolumn{5}{|c|}{ zbiory zamknięte } & \multicolumn{3}{c|}{ zbiory otwarte } \\
\cline { 2 - 7 } & $70 \%>$ & $50 \%$ & $50 \%<$ & $70 \%>$ & $50 \%$ & $50 \%<$ \\
\hline 1 rok & 60 & 52 & 48 & 55 & 50 & 55 \\
\hline 3 lata & 94 & 46 & 29 & 79 & 48 & 42 \\
\hline
\end{tabular}

którego odnosiły się zadania testowe był dzieciom znany (historia rozgrywająca się $\mathrm{w}$ kuchni i pokoju), jednak aby prawidłowo zinterpretować usłyszane kwestie, należało wykazać się dobrą znajomością składni oraz gramatyki, będących wyznacznikiem poziomu kompetencji językowych. Uzyskane wyniki pokazują, że 94 z badanych dzieci dopiero po trzech latach od implantacji osiąga zadawalające wyniki w interpretacji zadań i poleceń językowych w zestawach zamkniętych. Mniejsza liczba badanych (79 dzieci) osiąga wyniki powyżej 70\% trafności w obrębie zadań testowych ze zbiorów otwartych. Pozostała część grupy wymaga dalszej intensywnej stymulacji w obszarach językowych, które nie są wystarczająco rozwinięte.

Skala MUSS (tabela 10) dostarcza wyników w zakresie czynnego używania mowy do codziennej komunikacji przez dzieci zaimplan- 
Tabela 10. Wyniki - Skala MUSS - Skala Użycia Mowy Do Komunikacji, w zależności od czasu użytkowania wszczepu ( $\mathrm{N}=169)$

\begin{tabular}{|c|c|c|c|c|c|c|c|c|c|c|c|c|c|c|c|}
\hline \multirow{3}{*}{$\begin{array}{l}\text { Czas użytkowa- } \\
\text { nia wszczepu }\end{array}$} & \multicolumn{15}{|c|}{$\begin{array}{c}\text { Liczba dzieci z poszczególnymi wynikami w skalach używania } \\
\text { mowy do komunikacji }\end{array}$} \\
\hline & \multicolumn{5}{|c|}{$\begin{array}{l}\text { poziom kontroli } \\
\text { głosu }\end{array}$} & \multicolumn{5}{|c|}{ poziom użycia mowy } & \multicolumn{5}{|c|}{$\begin{array}{l}\text { poziom postawy } \\
\text { komunikacyjnej }\end{array}$} \\
\hline & 0 & 1 & 2 & 3 & 4 & 0 & 1 & 2 & 3 & 4 & 0 & 1 & 2 & 3 & 4 \\
\hline Od 3 do 6 lat & 0 & 0 & 3 & 40 & 23 & 0 & 0 & 12 & 33 & 21 & 0 & 0 & 13 & 35 & 18 \\
\hline Od 6 do 10 lat & 0 & 0 & 5 & 14 & 44 & 0 & 0 & 5 & 13 & 45 & 0 & 0 & 4 & 13 & 46 \\
\hline Od 10 do 14 lat & 0 & 0 & 0 & 7 & 31 & 0 & 0 & 0 & 6 & 32 & 0 & 0 & 0 & 8 & 30 \\
\hline Powyżej 14 lat & 0 & 0 & 0 & v & 2 & 0 & 0 & 0 & 0 & 2 & 0 & 0 & 0 & 0 & 2 \\
\hline Razem: & 0 & 0 & 8 & 61 & 100 & 0 & 0 & 17 & 52 & 100 & 0 & 0 & 17 & 56 & 96 \\
\hline
\end{tabular}

Legenda: 0 - nigdy, 1 - rzadko, 2 - czasami, 3 - często, 4 - zawsze

Tabela 11. Wyniki - Skala MAIS - Skala Słyszenia i Rozumienia Dźwięków w zależności od czasu użytkowania wszczepu ( $\mathrm{N}=169)$

\begin{tabular}{|c|c|c|c|c|c|c|c|c|c|c|c|c|c|c|c|}
\hline \multirow{3}{*}{$\begin{array}{l}\text { Czas użytkowa- } \\
\text { nia wszczepu }\end{array}$} & \multicolumn{15}{|c|}{$\begin{array}{l}\text { Liczba dzieci z poszczególnymi wynikami w skalach } \\
\text { słyszenia i rozumienia dźwięków }\end{array}$} \\
\hline & \multicolumn{5}{|c|}{$\begin{array}{l}\text { poziom akceptacji } \\
\text { urządzenia }\end{array}$} & \multicolumn{5}{|c|}{$\begin{array}{c}\text { pozom reakcji na } \\
\text { dźwięki }\end{array}$} & \multicolumn{5}{|c|}{$\begin{array}{l}\text { poziom rozumienia } \\
\text { znaczenia dźwięków }\end{array}$} \\
\hline & 0 & 1 & 2 & 3 & 4 & 0 & 1 & 2 & 3 & 4 & 0 & 1 & 2 & 3 & 4 \\
\hline Od 3 do 6 lat & 0 & 0 & 0 & 6 & 60 & 0 & 0 & 9 & 3 & 54 & 0 & 0 & 8 & 29 & 29 \\
\hline Od 6 do 10 lat & 0 & 0 & 0 & 3 & 60 & 0 & 0 & 0 & 6 & 57 & 0 & 0 & 0 & 11 & 52 \\
\hline Od 10 do 14 lat & 0 & 0 & 0 & 0 & 38 & 0 & 0 & 0 & 3 & 35 & 0 & 0 & 0 & 6 & 32 \\
\hline Powyżej 14 lat & 0 & 0 & 0 & 0 & 2 & 0 & 0 & 0 & 0 & 2 & 0 & 0 & 0 & 0 & 2 \\
\hline Razem: & 0 & 0 & 0 & 9 & 160 & 0 & 0 & 9 & 12 & 148 & 0 & 0 & 8 & 46 & 115 \\
\hline
\end{tabular}

Legenda: 0 - nigdy, 1 - rzadko, 2 - czasami, 3 - często, 4 - zawsze

towane. Zauważalne jest, że dzieci zaimplantowane spontanicznie używają mowy do porozumiewania się z członkami rodziny lub innymi ludźmi prawidłowo słyszącymi. W opinii własnej oraz rodziców wyposażenie w implant ślimakowy powoduje, że dzieci chętnie używają głosu, wypracowują w sobie gotowość i określoną 
postawę komunikacyjną, która skutkuje nawiązywaniem dialogów, a efektem końcowym takiego dyskursu jest uzyskanie potrzebnych informacji. Zaobserwować można, że w grupie użytkującej wszczep najkrócej, tj. do sześciu lat, jest większa liczba dzieci, która przejawia trudności w zakresie kontroli natężenia oraz barwy własnego głosu. Również poziom użycia mowy i wypracowanie postawy komunikacyjnej sprzyjającej nawiązywaniu kontaktów z innymi jest obarczone większymi trudnościami w stosunku do grupy dzieci użytkującej wszczep dłuższy czas. Wyniki uzyskane w Skali MAIS (tabela 11) również pokazują, że problemy związane z recepcją i złożonym procesem percepcji wszystkich otaczających dźwięków łącznie z mową zmniejszają się wraz z wydłużeniem czasu użytkowania wszczepu. Im dłuższy czas korzystania z implantu, tym lepsze efekty. Związane jest to z czasem, którego potrzebuje dziecko niesłyszące, aby przyswoić sobie wzorce językowe, które umożliwią budowanie i rozwijanie kompetencji językowych. Ten czas jest analogiczny jak w przypadku dzieci słyszących, które potrzebują około sześciu, siedmiu lat, aby stać się biegłymi użytkownikami języka ojczystego. Dziecko niesłyszące, chociaż zaimplantowane, nadal jest ograniczone niższym poziomem funkcjonowania słuchowego w stosunku do słyszących rówieśników, co może w konsekwencji zaburzać proces przetwarzania fonologicznego, który - jak wiadomo z doświadczenia terapeutycznego - warunkuje nabycie umiejętności analizy i syntezy fonemowej.

Analizując wyniki zawarte w tabeli 12, można zaobserwować, że dzieci, które użytkują wszczep ślimakowy najdłużej - powyżej 10 lat - uzyskują najwyższe noty we wszystkich badanych sferach. Można zauważyć, że kompetencje językowe wzrastają wprost proporcjonalnie do czasu użytkowania implantu ślimakowego. Użyty w badaniach Arkusz Badań Umiejętności Językowych pozwala na analizowanie $\mathrm{w}$ indywidualny sposób poziomu funkcjonowania językowego danego dziecka i na tej podstawie tworzenie wspierającego programu terapeutycznego, który ma za zadanie minimalizować braki i deficyty. Największą trudnością, z którą boryka się większość zaimplantowanych - nawet w tak wczesnym wieku dzieci - 
Tabela 12. Wyniki - Arkusz Badania Umiejętności Językowych - aktualny poziom wykonania $\mathrm{w}$ badanej grupie $\mathrm{w}$ zależności od czasu użytkowania wszczepu $(\mathrm{N}=169)$

\begin{tabular}{|l|c|c|c|c|}
\hline \multirow{2}{*}{$\begin{array}{c}\text { Umiejętności } \\
\text { językowe }\end{array}$} & \multicolumn{4}{|c|}{$\begin{array}{c}\text { Średni poziom wykonania testów umiejętności językowych dzieci } \\
\text { po różnym czasie użytkowania wszczepów }\end{array}$} \\
\cline { 2 - 5 } & $\begin{array}{c}\text { czas użytkowania } \\
\text { CI od 3 do 6 lat } \\
(\mathrm{N}=66)\end{array}$ & $\begin{array}{c}\text { czas użytkowania } \\
\text { CI od 6 do 10 lat } \\
(\mathrm{N}=63)\end{array}$ & $\begin{array}{c}\text { czas użytkowania } \\
\text { CI od 10 do 14 lat } \\
(\mathrm{N}=38)\end{array}$ & $\begin{array}{c}\text { czas użytkowania } \\
\text { CI powyżej 14 lat } \\
\text { (N = 2) }\end{array}$ \\
\hline Rozumienie & $58 \%$ & $65 \%$ & $75 \%$ & $98 \%$ \\
\hline Produkcja mowy & $70 \%$ & $75 \%$ & $80 \%$ & $100 \%$ \\
\hline Zasób pojęć & $45 \%$ & $65 \%$ & $70 \%$ & $95 \%$ \\
\hline Artykulacja & $70 \%$ & $85 \%$ & $88 \%$ & $97 \%$ \\
\hline
\end{tabular}

jest zbudowanie adekwatnego zasobu pojęć w stosunku do zasobów posiadanych przez słyszących rówieśników oraz minimalnej normy wiekowej. Najprawdopodobniej ta trudność związana jest z pozbawieniem możliwości odbioru cech akustycznych charakterystycznych dla danych przedmiotów, otaczających zjawisk, ludzi i zwierząt we wczesnym dzieciństwie, jeszcze przed implantacją. Nabycie i utrwalenie mechanizmu nieprawidłowego interpretowania rzeczywistości bez komponentów akustycznych skutkowało nieharmonijnym rozwojem poznawczym. Upośledziło to proces nabywania pojęć i skutkowało narastaniem dalszych opóźnień w rozwoju mowy i języka. Wyniki zawarte w tabeli 13. dotyczące aktualnego poziomu wykonania testu TAPS, pokazują wyraźny progres umiejętności w sferze funkcjonowania słuchowego badanych dzieci w stosunku do wyników osiągniętych w trzecim roku funkcjonowania $\mathrm{z}$ implantem ślimakowym. Aktualny poziom wykonania zadań testowych pokazuje, że możliwość wieloletniego dostępu do języka mówionego na drodze słuchowej po zaimplantowaniu w dużym stopniu daje szansę na pokonanie bariery fonetycznej ${ }^{16}(1)$,

16 Z.M. Kurkowski, Mowa dzieci sześcioletnich z uszkodzonym stuchem, UMCS, Lublin 1996, s. 60-70. 
z którą dzieci niesłyszące z głuchotą prelingwalną muszą się zmagać do końca życia. Wczesny wiek dzieci w momencie implantacji (do drugiego roku życia) pokazuje, że możliwe jest osiągnięcie kompetencji językowych zbliżonych do normy wiekowej, a język, którym posługują się badani, jest żywym, dynamicznym tworem, który podlega ciągłemu procesowi rozwoju. U większości dzieci z badanej grupy język jest funkcjonalny i służy do zaspakajania potrzeb również wyższego rzędu. Dzieciom zaimplantowanym nieobce jest sprawne poruszanie się w świecie abstrakcyjnych pojęć oraz twórcza asymilacja i akomodacja w sferze językowej.

Tabela 13. Wyniki w Teście TAPS, poziom IV, aktualny poziom wykonania w zależności od czasu użytkowania wszczepu ( $\mathrm{N}=169)$

\begin{tabular}{|l|c|c|c|c|c|c|}
\hline \multirow{2}{*}{$\begin{array}{c}\text { Czas użytkowania } \\
\text { wszczepu }\end{array}$} & \multicolumn{6}{|c|}{$\begin{array}{c}\text { Liczba dzieci z poszczególnymi poziomami wykonania testu: } \\
\text { rozpoznawanie, rozumienie mowy }\end{array}$} \\
\cline { 2 - 7 } & \multicolumn{3}{|c|}{ zbiory zamknięte } & \multicolumn{3}{c|}{ zbiory otwarte } \\
\cline { 2 - 7 } & $70 \%>$ & $50 \%$ & $50 \%<$ & $70 \%>$ & $50 \%$ & $50 \%<$ \\
\hline Od 3 do 6 lat & 60 & 5 & 1 & 55 & 9 & 2 \\
\hline Od 6 do 10 lat & 62 & 1 & 0 & 60 & 3 & 0 \\
\hline Od 10 do 14 lat & 38 & 0 & 0 & 38 & 0 & 0 \\
\hline Powyżej 14 lat & 2 & 0 & 0 & 2 & 0 & 0 \\
\hline
\end{tabular}

\section{Dyskusja}

Głuchota prelingwalna jest tym rodzajem głuchoty, z której konsekwencjami trzeba się borykać przez całe życie. Czynnik uszkadzający słuch występuje $\mathrm{w}$ okresie poprzedzającym czynny rozwój mowy. Brak możliwości słuchowej percepcji elementów suprasegmentalnych i segmentalnych mowy powoduje zaburzenia w zakresie dojrzewania kory słuchowej. Na szczęście dziecko niesłyszące nadal ma zachowaną tak zwaną fizjologiczną "postawę i gotowość" do nauki mowy, zwłaszcza do drugiego, a nawet trzeciego roku 
życia. Dlatego tak ważna jest jak najwcześniejsza implantacja17, która zapobiega powstaniu nieodwracalnych, negatywnych zmian w obrębie drogi słuchowej18. Dzieci operowane w Klinice Otolaryngologii UM w Poznaniu stanowią grupę, która została wyposażona w implant ślimakowy przed drugim rokiem życia. Wieloletnie obserwacje dotyczące funkcjonowania w sferze słuchowej oraz językowej po zaimplantowaniu pokazują, że badana grupa osiąga zadawalające efekty $w$ rehabilitacji mowy, lepsze jej rozumienie, szybszy przyrost słownictwa biernego i czynnego oraz większą autokontrolę głosu i poprawności wypowiadanych słów. Do podobnych wniosków doszła Gisela Szagun ${ }^{19}$, Richard T. Miyamoto ${ }^{20}$ oraz Anke Lesinski21, obserwując postępy rehabilitacyjne dzieci zaimplantowanych poniżej piątego oraz trzeciego roku życia.

W przedstawionych wynikach zaobserwować można różnicę pomiędzy grupami dzieci, które choć wszystkie były implantowane przed drugim rokiem życia, w zależności od czasu posługiwania się wszczepem ślimakowym w zróżnicowany sposób funkcjonują zarówno słuchowo i językowo. Im dłuższy czas czynnego korzystania ze wszczepu, tym lepsze wyniki w zakresie rozumienia mowy na drodze słuchowej oraz posługiwania się językiem w sytuacjach społecznych. Poczynione przez nas obserwacje wydają się być analo-

17 A.F.M. Snik, M.J.A. Makhdoum, The relations between age at the time of cochlear implantation and longterm speech perception abilities in congenitally deaf subjects, "Int. J. Pediatr. Otorhinolaryngol" 1997, 41, s. 121-131.

18 M. Manrique, A. Huarte, Indications and contrainications for cochlear implantation in children, "Am J Otol" 1998, s. 332-336.

${ }^{19} \mathrm{G}$. Szagun, The aquisition of grammatical and lexical structures in children with cochlear implants: a development psycholinquistic approach, "Audio Neurootol" 2000, 5, s. $39-47$.

${ }^{20}$ R.T. Miyamoto, K.I. Kirk, Speechperception and speech production skills of children with multichannel cochlear implants, "Acta Otolaryngol (Stockh)" 1996, 116, s. 240-243; R.T. Miyamoto, K.I. Kirk, Communication skills in pediatric cochlear implant recipients, “Acta Otolarynol (Stockh)" 1999, s. 219-224.

21 A. Lesinski, R.D. Battmer, Appropriate age for cochlear implantation in children: experenience since 1986 with 359 implanted children, "Adv. Otorhinolaryngol" 1997, 52, s. $214-217$. 
giczne do spostrzeżeń Pontona i wsp.22, którzy uważają, że w miarę trwania rehabilitacji związanej z czasem użytkowania CI wzrastają umiejętności słuchowe i werbalne zaimplantowanych dzieci. Wyniki uzyskane przez badaną grupę w Teście Słuchowej Percepcji Mowy (TAPS) wskazują, że po długoletniej rehabilitacji, dzieci są w stanie osiągnąć rozumienie mowy w zbiorach otwartych, a nawet umiejętność rozmowy przez telefon. Z naszych obserwacji wynika, że czas potrzebny na osiągnięcie takich umiejętności to sześć do siedmiu lat od momentu zaimplantowania przy systematycznym wsparciu terapeutycznym. Wielu autorów ${ }^{23}$ prezentuje wyniki podobne do uzyskanych w ośrodku poznańskim, mówiące, że po pięciu latach od implantacji wszystkie dzieci osiągają zrozumienie mowy w zbiorach otwartych w teście TAPS lub innych służących do oceny rozwoju słuchowej percepcji mowy.

Dzieci niesłyszące, wcześnie implantowane (średni wiek w momencie implantacji to 15 miesięcy) dość dobrze radzą sobie ze zrozumieniem komunikatów słownych, produkują dźwięki mowy, które mają znaczenie w systemie językowym, ale czy potrafią się skutecznie komunikować? ${ }^{24}$ Podstawowym celem rehabilitacji zaimplantowanych dzieci jest stymulacja rozwoju mowy dźwiękowej i języka we wszystkich jego aspektach, ze szczególnym uwzględnieniem zaawansowanego, adekwatnego tworzenia związków frazeologicznych. Badania prowadzone przy użycia narzędzia opracowanego w ośrodku poznańskim (Arkusz Badań Umiejętności Językowych) pokazują, że wieloletnie użytkowanie wszczepu ślimakowego (siedmioletnie i więcej) wydaje się być wystarczające do

${ }^{22}$ C.W. Ponton, J.J. Eggermont, M. Don, Maturation of the mimatch negativity effects of profound children and cochlear implant use, "Audiol. Neurootol" 2000, 5, s. 167-185.

${ }^{23}$ Ibidem; S. Archbold, M. Lutman, D. Marschal, Categories of auditory performance, "Ann. Otol. Rhinol.Laryngol" 1995, 104 (suppl.166), s. 312-31410; S. Archbold, M.E. Lutman, Categories of auditory performance: iner user reliability, “Br. J. Audiol" 1998, 32, s. 7-12; B. Mc Cornic, Audiometric evaluation of hearing loss in children, "Scand Audiol" 1997, 26 (suppl. 46), s. 26-31.

${ }^{24}$ A. Mc Conkey Robbins, M. Svirsky, Children with implants can speak but cant hey communicate?, “Otolaryngol Head Nesk Surg” 1997, 117, s. 155-160. 
tego, żeby język rozwinął się w stopniu wystarczającym do komunikowania się z innymi. Znajomość kodu językowego, choć w wielu przypadkach nadal nie jest doskonała i przejawia pewne ograniczenia, daje szansę dzieciom zaimplantowanym na codzienne twórcze odkrywanie i budowanie własnego, indywidualnego języka. Dzieci z implantem uzyskują dostęp do źródeł informacji, które wcześniej były dla nich niedostępne. Mają szansę na zdobywanie wiedzy na takich samych prawach co słyszący rówieśnicy i nie czują się wyobcowane ze środowiska, w którym dominującym kanałem percepcyjnym jest słuch i odbieranie za jego pośrednictwem dźwięków otoczenia i mowy ludzkiej.

\section{Wnioski}

1. Dzieci z głuchotą prelingwalną, zaimplantowane do drugiego roku życia, zdolne są do samodzielnego dostrzegania, rozróżniania, rozpoznawania i zapamiętywania bodźców akustycznych.

2. Poziom słuchowej percepcji dla poszczególnych grup badanych dzieci, determinowany jest między innymi czasem użytkowania wszczepu.

3. Proces rozwoju mowy i nabywania kompetencji językowych przez dzieci zaimplantowane podlega ciągłemu rozwojowi i doskonaleniu już nabytych struktur.

4. Wszystkie dzieci implantowane przed drugim rokiem życia osiągnęły taki poziom kompetencji językowych, który jest wystarczający do pełnoprawnego funkcjonowania w sferze językowej w środowisku ludzi słyszących.

\section{Bibliografia}

Archbold S., Lutman M., Marschal D., Categories of auditory performance, “Ann. Otol. Rhinol.Laryngol" 1995, 104 (suppl.166).

Archbold S., Lutman M.E., Categories of auditory performance: iner user reliability, “Br. J. Audiol” 1998, 32. 
Aronson L., Estienne P., Telephone speech comprehension in children with multichannel cochlear implants, "Am J Otol" 1997, 18 (suppl).

Broersen S., Cochleairr implantaat openet de wereld, "Medisch Contact" 2010, 65.

Demeńko G., Rychter L., Pruszewicz A. i in., Testy do badania stuchowej percepcji mowy (TBPSM) dla dzieci z implantami ślimakowymi, "Otolaryngologia Polska”, 1996, T. L50.

Geremek A., Skarżyński H., Szuchnik J., Program implantów ślimakowych u dzieci stan obecny, "Audiofonologia” Tom XIII, 1999.

Harrison R.V., Development of the Auditory System. From Periphery to Cortex, [w:] red. Richard C. Seewald, Anne Marie Tharpe, Comprehensive Handbook of Pediatric Audiology, Plural Pub., San Diego 2011.

Krakowiak K., Propozycje zmian systemowych w zakresie ksztatcenia dzieci i młodzieży ze specjalnymi potrzebami edukacyjnymi spowodowanymi przez uszkodzenia stuchu (niestyszacych, stabostyszacych, niedostyszacych), „CZEOWIEK - NIEPEŁNOSPRAWNOŚĆ - SPOŁECZEŃSTWO” 2016, nr 2(32).

Kurkowski Z.M., Mowa dzieci sześcioletnich z uszkodzonym stuchem, UMCS, Lublin 1996.

Leigh G., Newall J.P., Newall A.T., Newborn screening and earlier intervention with deaf children: Issues for developing world, [w:] The Oxford Handbook of deaf studies, language and education, vol. 2, red. M. Marschark, P. Spencer, Oxford University Press 2010.

Lesinski A., Battmer R.D., Appropriate age for cochlear implantation in children: experenience since 1986 with 359 implanted children, "Adv. Otorhinolaryngol" 1997, 52.

Manrique M., Huarte A., Indications and contrainications for cochlear implantation in children, "Am J Otol" 1998.

Mc Conkey Robbins A., Svirsky M., Children with implants can speak but can they communicate?, "Otolaryngol Head Nesk Surg” 1997, 117.

Mc Cornic B., Audiometric evaluation of hearing loss in children, "Scand Audiol" 1997, 26 (suppl. 46).

Miyamoto R.T., Kirk K.I., Communication skills in pediatric cochlear implant recipients, “Acta Otolarynol (Stockh)" 1999.

Miyamoto R.T., Kirk K.I, Speechperception and speech production skills of children with multichannel cochlear implants, "Acta Otolaryngol (Stockh)" 1996, 116.

Ponton C.W., Eggermont J.J., Don M., Maturation of the mimatch negativity effects of profound children and cochlear implant use, "Audiol. Neurootol" 2000, 5.

Porayski-Pomsta J., O rozwoju mowy dziecka. Dwa studia, Dom Wydawniczy Elipsa, Warszawa 2015.

Reid J., Bertram B., Tests of Auditory Perception of Speech for Children, by Cochlear AG, Basel, Switzerland, August 1992.

Robbins A.M., Osberger M.J., Meaningful Use of Speech Scale, Indiana University School of Medicine, 1991 (źródło: https:/ / digitalcommons.wustl.edu/cgi/view content.cgi?article=1309\&context=pacs_capstones [dostęp: 20.07.2018]. 
Robbins A.M., Developing meaningful auditory integration in children with cochlear implants, "Volta Review” 1990, 92.

Ruben R.J., A Time Frame of Critical/Sensitive Periods of Language Development, "IJO \& HNS" 1999, Vol. 51, No. 3, July-September.

Smoczyński P., Przyswajanie przez dziecko podstaw systemu jezykowego, Zakład im. Ossolińskich, Wrocław 1955.

Snik A.F.M., Makhdoum M.J.A, The relations between age at the time of cochlear implantation and longterm speech perception abilities in congenitally deaf subjects, "Int. J. Pediatr. Otorhinolaryngol" 1997.

Szagun G., The aquisition of grammatical and lexical structures in children with cochlear implants: a development psycholinquistic approach, "Audio Neurootol" 2000, 5.

Szkiełkowska A. Skarżyński H., Piotrowska A., Lorens A., Szuchnik J., Postępowanie u dzieci ze wszczepami ślimakowymi, „Otorynolaryngologia” 2008, 7(3).

Szyfter W., Pruszewicz A., Szmeja Z., Szymiec E. i in., Poznański Program leczenia głuchoty dziecięcej metodą wszczepów ślimakowych, "Otolaryngologia Polska” 1997, Tom L, Suplement 22. https:/ / whc.ifps.org.pl/2018/02/miedzynarodowy-dzienimplantu-slimakowego-2/ [dostęp: 20.04.2018]. 